\title{
INFLUENCE OF PHYSICO-CHEMICAL FACTORS ON THE ZOOPLANKTON POPULATION OF BOSTAMI POND OF CHITTAGONG
}

\author{
Sajeda Akter*, Abdul Maleque Bhouyain, Subarna Azad and Dilshad Nasrin \\ Department of Zoology, University of Chittagong, Chittagong 4331, Bangladesh
}

\begin{abstract}
The study was conducted on the influence of physico-chemical factors on the zooplankton of Bostami pond in Chittagong city for a period of one year from February 2013 to January 2014. During this study the water depth varied from 1.54 to $2.53 \mathrm{~m}$, water temperature 24.5 to $32.6^{\circ} \mathrm{C}$, conductivity 0.234 to $0.297 \mathrm{mS}$, turbidity 26.55 to $33.41 \mathrm{ntu}$, light intensity 27 to 39.5 lux, total dissolved solids 161 to $191 \mathrm{ppm}, \mathrm{pH} 7.02$ to 7.79 , dissolved oxygen 3.4 to 5.73 ppm, free carbon dioxide 2.82 to $5.85 \mathrm{ppm}$, and calcium 25.08 to $43.03 \mathrm{ppm}$. It was found that the temperature was less during February 2013 and gradually increased up to June 2013. Then with a break in July it gradually decreased until the next January 2014. More or less reverse data observed for the monthly variation of conductivity, total dissolved solids and calcium. Free carbon dioxide is inversely related with water depth and $\mathrm{pH}$. In total 19 species of zooplankton were identified, where 16 rotifera were the dominant followed by two copepods and one cladoceran. Among these, Brachionus diversicornis, $B$. angularis, $B$. quadridentatus, B. falcatus, B. calyciflorus, B. forficula, B. caudatus, Platyias patulus, Keratella cochlearis, Lecane luna, Trichocerca cylindrica, Polyarthra vulgaris, Asplanchna priodonta, A. brightwelli, Filinia longiseta, F. terminalis, Mesocyclops leuckarti, Cyclops varicans rubellus and Moina brachiata were the most common species in the pond throughout the year. Abundance of phytoplankton and zooplankton indicated that the nutrient quality of the pond water was good. The total phytoplankton varied from 842 to 2223 individuals/1 and total zooplankton 187 to 494 individuals/1; with rotifera 105 to 266 individuals/1, copepoda 43 to 135 individuals/1 and cladocera from 39 to 115 individuals $/ 1$ throughout the year. Plankton abundance and physico-chemical characteristics of the Bostami pond indicate that the pond is eutrophic in nature.
\end{abstract}

Key words: Plankton population, zooplankton, physico-chemical factors, Bostami pond.

\section{INTRODUCTION}

Bangladesh has an unique geographical location in the humid tropical and subtropical regions with high rainfall during monsoon. It has many different types of water bodies such as ponds, lakes, rivers, etc. (Ali 1985). The quality of water determines the distribution and abundance of aquatic flora and fauna (Rana 2003), where the zooplankton forms the principal source of food for fish within the water body (Prasad and Singh 2003). Zooplankton also plays very

\footnotetext{
*Corresponding author: ambhouyain@yahoo.com, Fazlur Rahman School \& College, Chittagong.
} 
important role in the food chain as they are in the second trophic level as contributors to the higher trophic level (Bhuiyan and Islam 1988). They regulate the phytoplankton population by eating and again they are being eaten by insects or by small fishes (Welch 1952). Moreover, with the advent of knowledge zooplankton are used as indicator by the pollution experts to assess the level of pollution of water body caused by human activities (Bhouyain and Asmat 1992).

Considerable works have been done on the water bodies of Bangladesh by different authors. (Begum 1958, Das 1974, Das and Bhuiyan 1974, Islam et al. 1974, Islam and Saha 1975, Islam and Haroon 1975, Islam and Mendes 1976, Hussain et al. 1978, Islam et al. 1978, Majumdar 1980, Chowdhury and Bhouyain 1981, Bhouyain and Sen 1983, Ameen et al. 1986, Latif et al. 1986, Chowdhury et al. 1989, Begum et al. 1989, Khondkar et al. 1990, Bhouyain and Sen 1991, Khondkar and Rahim 1991, Chowdhury et al.1992, Khondkar and Parveen 1992, Hossain et al. 1993, Khan and Chowdhury 1994, Kabir et al. 1996, Kabir et al. 1997, Bhuiyan and Nessa 1998a, Bhuiyan and Nessa 1998b, Ahmed et al. 1999, Islam et al. 2002, Rahaman 2004, Bhouyain et al. 2005, Azher et al. 2006, Chowdhury and Mamun 2006, Bhuiyan et al. 2008, Rahman et al. 2007, Naz and Najia 2008, Chowdhury et al. 2008, Hossain et al. 2008, Nahar et al. 2008, Ahmed et al. 2010, Siddique et al. 2011, Mozumder et al. 2011 and Hossain and Haque 2012).

Chittagong is the second largest metropolitan city of Bangladesh. It is bounded by a large number of different types of pond. Bostami pond is one of the famous ponds in Chittagong and situated at the northern side of Chittagong city. The famous mazar of Hazrat Bayezid Bostami (R) is situated at the western side of the pond. The pond is so much famous in home and abroad for its mazar and the turtles which are very much uncommon. Recently, Bangladesh government has declared it as a Ecologically Sensitive Area (ESA) and has given emphasis on its protection.

The purpose of the present work was to assess the physico-chemical and biological aspects of an important water body and to observe the influence of physico-chemical factors on the plankton composition. So, an attempt was taken to measure the physico-chemical parameters viz., water depth, water temperature, conductivity, turbidity, total dissolved solids, $\mathrm{pH}$, dissolved oxygen, free carbon dioxide and tried to relate them with biological parameters viz., phytoplankton and zooplankton (rotifera, copepoda and cladocera).

The main objectives of the present study was as follows:

(i) Identify the zooplanktonic organisms of the Bayezid Bostami pond.

(ii) Measure the physico-chemical properties of the pond water.

(iii) Observe the influence of physico-chemical parameters on the abundance of the phytoplankton and zooplankton population. 


\section{MATERIAL AND METHODS}

Two sampling points were selected for the collection of water and plankton sample at the two site of the pond. Samples were collected in each month for one year from February, 2013 to January, 2014. During the study period the samplings were done in between 7:30 and 11:30 a.m.

Water depth was measured by dipping a weighted nylon cord. A centigrade thermometer was used to record water temperature (ELFO Co., Japan). The conductivity was measured by conductivity meter (Model: YK-22CT, Taiwan). The turbidity was measured by turbidity meter (Model: TU-2016, Taiwan). The light intensity was measured by lux meter (Model: LX-101, China). The total dissolved solids was measured by total dissolved solids meter (Model: TU-2016, Taiwan).

Chemical parameters such as $\mathrm{pH}, \mathrm{DO}$, free $\mathrm{CO}_{2}$ and calcium have been studied during this investigation. The hydrogen ion concentration $(\mathrm{pH})$ was measured by $\mathrm{pH}$ meter (Model: 208, Digital Instrument,Taiwan).The Azide modification method was used during this study for the determination of dissolved oxygen. The analysis of free carbon dioxide was conducted by Titrimetric method following APHA, 1975. EDTA titrimetric method was used to measure the free carbon dioxide concentration.

Plankton samples were collected from each station by using plankton net. The net was thrown to the desired distance and allowed to reach the desired depth of the sampling station from a raft. Then the thrown rope with net was pulled quickly towards the raft for the collection of the plankton samples. The net was pulled five times from several places of each station. The collected samples were preserved by adding $10 \mathrm{ml}$ of commercial formalin to $100 \mathrm{ml}$ of sample. The volume of final concentrate was made into $110 \mathrm{ml}$. Sedgwick-Rafter Cell (Model: S50, Sedgu-Graticules Limited,UK) was used to count the total number of plankton. Each sample was counted for five times and each time 10 cells were observed out of 1000 cells. Thus from the total number of planktons obtained in $1 \mathrm{ml}$, the total number of plankton in $110 \mathrm{ml}$ was calculated. The formula: $\pi r^{2} \mathrm{~L}$ (where ' $\mathrm{r}$ ' is the radius of the mouth of the plankton net, and ' $\mathrm{L}$ ' is the length of the rope) was used to calculate the volume of water passed in each tow and which was multiplied by 5 tow for obtaining total volume of water containing the number of planktons in 5 tows. Thus plankton numbers present in one liter of water was calculated. The population of zooplankton (rotifera, copepoda, cladocera) and phytoplankton were counted under the compound binocular microscope (Model: XSZ-107B, China). 


\section{RESULTS AND DISCUSSION}

The monthly fluctuations of water depth have been presented in Table 1 . The highest water depth $2.52 \mathrm{~m}$ was recorded in the month of July, 2013. The water depth started to decrease from August and reached to its lowest depth $1.54 \mathrm{~m}$ in June. The highest water depth in August was recorded by Saha et al. (1971), Swarup and Singh (1979), Bhouyain and Sen (1991) and Khondkar and Parveen (1992). Rahman et al. (2007) recorded highest water depth in September.

The lowest water depth $1.54 \mathrm{~m}$ was recorded in June, 2013 (Table 1). Bhouyain and Sen (1991) and Ameen et al. (1986) recorded the minimum water depth in March. Latif et al. (1986), Khondkar and Parveen (1992), and Bhouyain et al. (2005) recorded the lowest water depth in April. Rahman et al. (2007) also recorded the lowest water depth in April. In this study it has been also recorded that the water depth started to decrease from February, 2013 and reached to its lowest depth in June, 2013 and then started to increase until August, 2013.

The data of water temperature are presented in Table 1 . The highest water temperature was recorded in the month of June, 2013 (Table 1). Similar result of highest water temperature in June was also reported by many researchers from different water bodies (Mathew 1975, Swarup and Singh 1979, Ramakrishnaiah and Sakar 1982, Latif et al. 1986, Bhouyain and Sen 1991, and Khondkar and Parveen 1992). Islam and Saha (1975) recorded the highest water temperature in April. Saha et al. (1971), Ameen et al. (1986), Chowdhury et al. (1989), Begum et al. (1989) and Chowdhury et al. (1992) observed the highest water temperature in May. Islam and Mendes (1976) reported highest water temperature in August. Bhouyain et al. (2005) recorded the highest water temperature in May. Siddique et al. (2011) reported the highest water temperature in September.

The lowest water temperature $24.5^{\circ} \mathrm{C}$ was recorded from Bayezid Bostami pond in the month of January (Table 1) which was also recorded by Saha et al. (1971), Islam and Mendes (1976), Swarup and Singh (1979), Ramakrishnaiah and Sakar (1982), Chowdhury et al. (1989) and Chowdhury et al. (1992) from other water bodies. Latif et al. (1986), Bhouyain and Sen (1991), and Khondkar and Parveen (1992) also recorded the lowest water temperature in February. Ameen et al. (1986) and Begum et al. (1989) recorded the lowest water temperature in December. Bhouyain et al. (2005) recorded the lowest water temperature in January. Siddique et al. (2011) recorded the lowest water temperature in February.

The conductivity of the Bayezid Bostami pond water was found to be fluctuating throughout the study period which ranged from 0.234 to $0.297 \mathrm{mS}$ (Table 1). The highest conductivity was recorded in the month of January, 2014 (Table 1). From February, 2013 to June, 2013 it was decreased showing the 
values of $0.273,0.266,0.253,0.243$ and $0.235 \mathrm{mS}$, respectively. Vyes and Kumar (1968) observed the highest conductivity in September. Ramakhrishmaiah and Sarkar (1982) observed the highest conductivity in May. Campos et al. (1992) recorded the maximum conductivity in January.

The lowest conductivity was recorded in the month of July, 2014 (Table 1). Then from August, 2013 to December, 2013 it was increased showing the values of $0.264,0.282,0.291,0.293$ and $0.295 \mathrm{mS}$, respectively. Vyes and Kumar (1968) also observed the minimum conductivity in May. Ramakhrishmaiah and Sarkar (1982) observed the lowest conductivity in November. Nessa (1996) recorded the lowest conductivity in May.

The turbidity showed monthly variation and the data are presented in Table 1. The highest turbidity $33.41 \mathrm{ntu}$ was recorded in the month of June, 2013 and lowest turbidity $26.55 \mathrm{ntu}$ in September, 2013 was seen in Bayezid Bostami pond (Table 1). The turbidity of pond water was found to be fluctuating from $31.11 \mathrm{ntu}$ recorded in February, 2013. It was increased showing the values 31.32 and 33.24 ntu in March and April 2013, respectively. Then it was decreased showing the turbidity $28.74 \mathrm{ntu}$. Then it was again increased and showed its highest turbidity $33.41 \mathrm{ntu}$ in June, 2013. Then again it was decreased showing the values 30.35, 26.95 and 26.55 ntu in July, August and September, respectively. Then it was again increased showing the values 27.27, 27.63, 28.11 and 28.18 ntu in October, November, December and January, respectively.

The variations of light intensity are showing in Table 1. The highest light intensity 39.5 lux was recorded in the month of February, 2013 (Table 1). March, 2013 to November, 2013 it was gradually decreased showing the values of $37,36,35,34.5,34,33.5,32.5,30.5$ and 31 lux, respectively. The lowest light intensity 27 lux was recorded in the month of December, 2013 (Table 1).

The total dissolved solids of the pond water were observed through out the study period which ranged from 161 to $191 \mathrm{ppm}$ (Table 1). The highest total dissolved solids $191 \mathrm{ppm}$ was recorded in the month of January, 2014 shown in Table 1. February, 2013 to July, 2013 it was gradually decreased showing the values of $181,181,178,163,162$ and $161 \mathrm{ppm}$, respectively. Then it was increased in the month of August, 2013 having the total dissolved solids 168 ppm. The lowest total dissolved solids $161 \mathrm{ppm}$ was recorded in the month of July, 2013 (Table 1).

The data of hydrogen ion concentration $(\mathrm{pH})$ are presented in Table 1 . The $\mathrm{pH}$ value of the pond showed to be alkaline in nature during the study period with small variation (Table 1). The alkaline nature of water also reported by Islam and Mendes (1976), Swarup and singh (1979), Ameen et al. (1986), Latif et al. (1986), Begum et al. (1989), Khondkar and Parveen (1992), Chowdhury 
et al. (1992), Bhouyain et al. (2005), Rahman et al. (2007), Latifa et al. (2008), Ahmed et al. (2010), and Siddique et al. (2011). The highest $\mathrm{pH}$ value 7.79 was recorded in May, 2013 (Table 1) in the present study. Similar results were observed by Ameen et al. (1986) and Latif et al. (1986). Chowdhury et al. (1989), Bhouyain and Sen (1991), Khondkar and Parveen (1992), Chowdhury et al. (1992) recorded the highest $\mathrm{pH}$ value in April. Rahman et al. (2007) recorded in August, Latifa et al. (2008) recorded in March, Ahmed et al. (2010) recorded in June, and Siddique et al. (2011) recorded in February. The high pH due to high temperature, low free $\mathrm{CO}_{2}$, high photo-synthesis and low rainfall in summer months.

The lowest value 7.02 was recorded in January, 2014 (Table 1). Similar observation was also recorded by Islam and Mendes (1976), and Ahmed et al. (2010). Shil (1980) recorded it in October at Kamal dighi and in September at Lal dighi, Begum et al. (1989) recorded in October and Chowdhury et al. (1992) recorded this in September. Bhouyain et al. (2005), Rahman et al. (2007), Latifa et al. (2008) and Siddique et al. (2011) recorded in January, December, September and October respectively. Mamun et al. (2010) reported the highest value of $\mathrm{pH}$ in October.

The monthly abundance of dissolved oxygen are showing in Table 1. The highest dissolved oxygen $5.73 \mathrm{ppm}$ was recorded in the month of January, 2014 (Table 1). The maximum dissolved oxygen was recorded in November by Islam and Mendes (1976), Khondkar and Parveen (1992). The concentration of dissolved oxygen was maximum in winter month. It is also noticed by Welch (1952), Swarup and Singh (1979), Ameen et al. (1986), Begum et al. (1989) and Bhouyain et al. (2005). Ahmed et al. (1999) recorded the highest dissolved oxygen during monsoon season. Hossain et al. (1998) reported the highest dissolved oxygen in May. Kabir and Naser (2008) reported the highest dissolved oxygen in May. Rahman et al. (2007), Latifa et al. (2008), Ahmed et al. (2010) and Siddique et al. (2011) recorded the highest dissolved oxygen in June, March, November and September respectively. The high concentration of dissolved oxygen content during winter month possibly due to the low rainfall and low volume of water.

The lowest dissolved oxygen $3.4 \mathrm{ppm}$ was recorded in the month of August, 2013 (Table 1). The similar observation was also recorded by Islam and Mendes (1976), and Ameen et al. (1986). Hossain et al. (1998) reported the lowest dissolved oxygen in December. Bhouyain et al. (2005) reported the lowest dissolved oxygen in August. The lowest dissolved oxygen was recorded in November by Rahman et al. (2007). Kabir and Naser (2008) reported the lowest dissolved oxygen in July. Latifa et al. (2008) reported the lowest dissolved oxygen in May. Mamun et al. (2010) reported the lowest dissolved oxygen in June. Siddique et al. (2011) reported the lowest dissolved oxygen in October. 
In this work the highest free carbon dioxide $5.85 \mathrm{ppm}$ was noticed in the month of January, 2014 (Table 1). Chowdhury (1997) recorded the highest free carbon dioxide in May. Iqbal (1998) reported the highest free carbon dioxide in April. Bhouyain et al. (2005) recorded the highest free carbon dioxide in January. Rahman et al. (2007) recorded the highest free carbon dioxide in November. Kabir and Naser (2008) recorded the highest free carbon dioxide in November. Latifa et al. (2008) recorded the highest free carbon dioxide in June. Ahmed et al. (2010) the highest free carbon dioxide was recorded in June. Siddique et al. (2011) recorded the highest free carbon dioxide in February.

The lowest free carbon dioxide $2.82 \mathrm{ppm}$ was recorded in the month of September, 2013 (Table 1). Majumder (1980) recorded the lowest free carbon dioxide in the month of March. The minimum concentration of free carbon dioxide in March observed by Sen (1982). Chowdhury (1997) recorded the lowest free carbon dioxide in March. Iqbal (1998) reported the lowest free carbon dioxide in January. The lowest free carbon dioxide also recorded by Bhouyain et al. (2005) in November, Rahman et al. (2007) in June, Latifa et al. (2008) in February, Ahmed et al. (2010) in July and Siddique et al. (2011) in September.

Calcium: The calcium concentration of the Bayezid Bostami pond showed a clear seasonal and monthly trends of fluctuations (Table 1). The highest calcium concentration 43.03 ppm was recorded in January, 2014 (Table 1). Swarup and Singh (1979) recorded the highest calcium concentration in January. Saha et al. (1971) noted higher calcium concentration in summer. Campos et al. (1992) recorded the maximum calcium concentration in February. Chowdhury (1997) recorded the highest calcium concentration in April. Iqbal (1998) reported the highest calcium concentration in February. Bhouyain et al. (2005), Ahmed et al. (2010) and Rahman et al. (2007) reported the highest calcium concentration in August. Latifa et al. (2008) recorded the highest calcium concentration in August. Kabir and Naser (2008) recorded the highest calcium concentration in September.

The lowest calcium concentration $25.08 \mathrm{ppm}$ was recorded in October, 2013 (Table 1). Similar result was also recorded by Swarup and Singh (1979). Saha et al. (1971) noted the lowest calcium concentration in winter. Campos et al. (1992) recorded the minimum calcium in July. Chowdhury (1997) recorded the lowest calcium concentration in October. Iqbal (1998) reported the lowest calcium concentration in September. Bhouyain et al. (2005) and Latifa et al. (2008) recorded the lowest calcium concentration in November. Rahman et al. (2007), Kabir and Naser (2008), and Ahmed et al. (2010) recorded the lowest calcium concentration in April, September and June, respectively. The lowest calcium concentration after rainy season was probably due to dilution by rain water. The Bayezid Bostami pond can be classified as rich depending upon calcium content. 
The fluctuations of phytoplankton population were observed in Table 1 . The highest number of phytoplankton 2223 individuals/1 was observed in September, 2013 (Table 1) in this study. Hossain et al. (1998) observed two high peaks, one in May and second in October. The phytoplankton densities increased in spring as light increased observed by Rahman et al. (2007). A large number of phytoplankton genera and seasonal succession of phytoplankton population were observed by Rahman et al. (2007). The highest number of phytoplankton population was observed due to clean weather, highest light penetration, comparatively higher free carbon dioxide and high rate of photosynthesis. The lowest number of phytoplankton 842 individuals/1 was recorded in March, 2013 (Table 1). Rahman et al. (2007) the population densities were relatively lowest in October and the lowest peak appeared in January. The lowest number was observed in March due to low light penetration, comparatively lowered free carbon dioxide and low rate of photosynthesis.

During the study period a distinct fluctuation of zooplankton population in different months was observed (Table 1). In the present study, rotifera, copepoda and cladocera are represented in Table 1. The zooplankton 494 individuals/1 showed its maximum abundance in September, 2013 (Table 1). Begum et al. (1989) recorded the peak abundance in March. Bhouyain et al. (2005) recorded maximum abundance in September. The highest number of zooplankton in autumn was observed by Saha et al. (1971), Ramakrishnaiah and Sakar (1982). Begum et al. (1989) recorded the peak abundance in March. The highest number of zooplankton in autumn was possibly due to comparatively low light penetration, comparatively low amount of free carbon dioxide.

The lowest number of zooplankton 187 individuals/1 was recorded in March, 2013 (Table 1).

Rotifera: The data of rotifera are presented in Table 1 . The highest number of rotifera 266 individuals/1 was recorded in September, 2013 (Table 1). Saha et al. (1971) recorded the highest number of rotifera in November. Bhouyain et al. (2005) recorded the highest number of rotifera in November. Chowdhury and Raknuzzaman (2005) recorded the highest number of rotifera in May. Rahman and Hussain (2008) reported peak season of rotifera in January. Siddique et al. (2011) recorded the highest number of rotifera in February. The highest number of rotifera was found due to the suitable environment, favourable conditions of physico-chemical parameters and the availability of food and nutrients in the pond. The lowest number of rotifera 105 individuals/1 was recorded in March, 2013 (Table1). Bhouyain et al. (2005) recorded the lowest number of rotifera in March. Chowdhury and Raknuzzaman (2005) recorded the lowest number of rotifera in September. Siddique et al. (2011) recorded the lowest number of rotifera in October. 16 species of rotifera was identified during the study period. 
The genera Brachionus, Asplanchna, Lecane, Filinia, Platyias, Keratella, Polyarthra, Trichocerca were found throughout the study period. Saha et al. (1971), Begum et al. (1989) also recorded similar type of observation. Bhouyain and Asmat (1992) recorded 25 species, Chowdhury and Raknuzzaman (2005) identified 12 genera, Mozumder et al. (2010) identified 31 taxa and Mozumder et al. (2011) identified 22 genera of rotifera.

The number of copepoda was varied from 43 to 135 individuals/1 where the highest was recorded in September, 2013 (Table 1). Das and Srivastava (1956) divided their entire investigation year into various dominant periods such as September, October and November constituted the copepodan period. The highest number of copepoda in autumn was recorded by Saha et al. (1971), Ramakrishnaiah and Sakar (1982) and Begum et al. (1989). Bhouyain et al. (2005) recorded the highest number of copepoda in October. Rahman and Hussain (2008) recorded peak season of copepods in September. Siddique et al. (2011) recorded the highest number of copepoda in February. The lowest number of copepoda 43 individuals/1 was recorded in March, 2013 (Table1). Bhouyain et al. (2005) recorded the lowest number of copepoda in March. Chowdhury and Raknuzzaman (2005) recorded the lowest number of copepoda in February. Siddique et al. (2011) recorded the lowest number of copepoda in September. Irregularity of the copepods at different months might be due to the fact that different species involved had their maximum and minimum occurring at different times. 2 species of copepods were identified during study period. Bhouyain and Asmat (1992) recorded 10 species, Chowdhury and Raknuzzaman (2005) identified 4 genera, Mozumder et al. (2010) identified 5 taxa.

The cladocera was shown in Table 1. The highest number of cladocera 115 individuals/1 was recorded in October, 2013 (Table 1). Das and Srivastava (1956) divided their entire investigation year into various dominant periods such as December and January constituted the cladocerans period. Begum et al. (1989) noticed it in March. Bhouyain et al. (2005) recorded the highest number of cladocera in the month of July. Rahman and Hussain (2008) reported peak season of cladocera in January. Siddique et al. (2011) recorded the highest number of cladocera in February. The highest number was shown due to the favourable conditions of the environment.

The lowest number of cladocera 39 individuals/1 were recorded in March, 2013 (Table 1). Bhouyain et al. (2005) recorded the lowest number of cladocera in March and December. Siddique et al. (2011) recorded the lowest number of cladocera in October. The lowest number of cladocera were found due to the unfavourable conditions of the environment in the pond. 2 species of cladocerans were identified during the study period. Bhouyain and Asmat (1992) recorded 14 species, Chowdhury and Raknuzzaman (2005) identified 6 genera, Mozumder et al. (2010) identified 5 taxa. 
From the statistical analyses it has been observed that water depth showed positive correlation with conductivity $(\mathrm{r}=0.460671)$, total dissolved solids $(\mathrm{r}=$ $0.209221)$, phytoplankton $(r=0.705899)$, zooplankton $(r=0.706033)$, rotifera $(r=0.693527)$, copepoda $(r=0.672022)$ and cladocera $(r=0.685201)$ while inversely related with water temperature $(\mathrm{r}=-0.27148)$, turbidity $(\mathrm{r}=-0.67769)$, light intensity $\quad(\mathrm{r}=-0.45883), \mathrm{pH}(\mathrm{r}=-0.58268), \mathrm{DO}(\mathrm{r}=-0.12364), \mathrm{CO}_{2}(\mathrm{r}=-$ $0.29967)$ and $\mathrm{Ca}(\mathrm{r}=-0.36948)$.

Water temperature showed positive correlation with turbidity $(\mathrm{r}=0.214818)$, light intensity $(\mathrm{r}=0.222867), \mathrm{pH}(\mathrm{r}=0.432564)$, copepoda $(\mathrm{r}=0.095395)$ and cladocera $(r=0.005732)$ while inversely related with conductivity $(r=-0.52376)$, total dissolved solids $(\mathrm{r}=-0.66934)$, DO $(\mathrm{r}=-0.74676), \mathrm{CO}_{2}(\mathrm{r}=-0.60122)$, Ca ( $\mathrm{r}$ $=-0.60846)$, phytoplankton $(\mathrm{r}=-0.01773)$, zooplankton $(\mathrm{r}=-0.01714)$ and rotifera $(\mathrm{r}=-0.08567)$.

Conductivity showed positive correlation with total dissolved solids $(\mathrm{r}=$ 0.877554), DO $(\mathrm{r}=0.495264), \mathrm{CO}_{2} \quad(\mathrm{r}=0.240759), \mathrm{Ca}(\mathrm{r}=0.166984)$, phytoplankton $(\mathrm{r}=0.621081)$, zooplankton $(\mathrm{r}=0.620661)$, rotifera $(\mathrm{r}=0.70139)$, copepoda $(r=0.525426)$ and cladocera $(r=0.469583)$ while inversely related with turbidity $(r=-0.63596)$, light intensity $(r=-0.55084)$ and $\mathrm{pH}(\mathrm{r}=-$ $0.70245)$.

Turbidity showed positive correlation with light intensity $(\mathrm{r}=0.620516), \mathrm{pH}$ $(\mathrm{r}=0.20055)$, $\mathrm{DO}(\mathrm{r}=0.095448), \mathrm{CO}_{2}(\mathrm{r}=0.424087)$ and $\mathrm{Ca}(\mathrm{r}=0.398395)$ while inversely related with total dissolved solids $(\mathrm{r}=-0.24527)$, phytoplankton $(\mathrm{r}=-0.81717)$, zooplankton $(\mathrm{r}=-0.81699)$, rotifera $(\mathrm{r}=-0.80631)$, copepoda $(\mathrm{r}=$ $-0.75586)$ and cladocera $(\mathrm{r}=-0.81091)$.

Light intensity showed positive correlation with $\mathrm{pH}(\mathrm{r}=0.286063)$, DO $(\mathrm{r}=$ $0.111119), \mathrm{CO}_{2}(\mathrm{r}=0.363533)$ and $\mathrm{Ca}(\mathrm{r}=0.2767)$ while inversely related with total dissolved solids $(\mathrm{r}=-0.31618)$, phytoplankton $(\mathrm{r}=-0.67905)$, zooplankton $(\mathrm{r}=-0.67882)$, rotifera $(\mathrm{r}=-0.62242)$, copepoda $(\mathrm{r}=-0.6545)$ and cladocera $(\mathrm{r}=-0.75166)$.

Total Dissolved Solids showed positive correlation with DO $(\mathrm{r}=0.728013)$, $\mathrm{CO}_{2}(\mathrm{r}=0.637039), \mathrm{Ca}(\mathrm{r}=0.559291)$, phytoplankton $(\mathrm{r}=0.20775)$, zooplankton $(\mathrm{r}=0.207231)$, rotifera $(\mathrm{r}=0.313859)$, copepoda $(\mathrm{r}=0.114532)$ and cladocera $(\mathrm{r}$ $=0.046576)$ while inversely related with $\mathrm{pH}(\mathrm{r}=-0.74093)$.

$\mathrm{pH}$ showed negative correlation with DO $(\mathrm{r}=-0.43779), \mathrm{CO}_{2}(\mathrm{r}=-0.3914)$, Ca $(\mathrm{r}=-0.22047)$, phytoplankton $(\mathrm{r}=-0.37107)$, zooplankton $(\mathrm{r}=-0.37083)$, rotifera $(\mathrm{r}=-0.46506)$, copepoda $(\mathrm{r}=-0.30898)$, and cladocera $(\mathrm{r}=-0.17969)$.

DO showed positive correlation with $\mathrm{CO}_{2}(\mathrm{r}=0.878696)$ and $\mathrm{Ca}(\mathrm{r}=$ 0.855547) while inversely related with phytoplankton $(\mathrm{r}=-0.19119)$, zooplankton $(\mathrm{r}=-0.19176)$, rotifera $(\mathrm{r}=-0.0467)$, copepoda $(\mathrm{r}=-0.31303)$ and cladocera $(\mathrm{r}=-0.35465)$. 
Influence of physico-chemical factors

Table 1. Monthly variation of physical, chemical and biological parameters of Bayezid Bostami pond during February, 2013 to January, 2014

\begin{tabular}{lllllllllllllll}
\hline $\begin{array}{l}\text { Months } \\
\text { Parameters }\end{array}$ & Unit & Feb. & Mar. & Apr. & May & Jun. & Jul. & Aug. & Sep. & Oct. & Nov. & Dec. & Jan. \\
\hline Water depth & $\mathrm{m}$ & 2.03 & 1.97 & 1.83 & 1.62 & 1.54 & 2.53 & 2.52 & 2.37 & 2.35 & 2.32 & 2.29 & 2.15 \\
Temperature & ${ }^{\circ} \mathrm{C}$ & 27.8 & 28.4 & 30.3 & 29.5 & 32.6 & 27.7 & 31.5 & 30.7 & 29.7 & 27.8 & 26.8 & 24.5 \\
Conductivity & $\mathrm{mS}$ & 0.273 & 0.266 & 0.253 & 0.243 & 0.235 & 0.234 & 0.264 & 0.282 & 0.291 & 0.293 & 0.295 & 0.297 \\
Turbidity & $\mathrm{ntu}$ & 31.11 & 31.32 & 33.24 & 28.75 & 33.41 & 30.35 & 26.95 & 26.55 & 27.27 & 27.63 & 28.11 & 28.18 \\
Light intensity & lux & 39.5 & 37 & 36 & 35 & 34.5 & 34 & 33.5 & 32.5 & 30.5 & 31 & 27 & 32 \\
TDS & $\mathrm{ppm}$ & 180 & 181 & 178 & 163 & 162 & 161 & 168 & 174 & 179 & 184 & 187 & 191 \\
pH & - & 7.14 & 7.11 & 7.24 & 7.79 & 7.38 & 7.27 & 7.2 & 7.15 & 7.16 & 7.1 & 7.06 & 7.02 \\
DO & $\mathrm{ppm}$ & 5.67 & 4.48 & 4.06 & 3.83 & 3.68 & 3.5 & 3.4 & 3.62 & 3.76 & 4.02 & 4.94 & 5.73 \\
Free CO 2 & $\mathrm{ppm}$ & 5.57 & 5.32 & 4.91 & 3.31 & 3.53 & 3.18 & 3.01 & 2.82 & 2.92 & 3.66 & 4.35 & 5.85 \\
Calcium & $\mathrm{ppm}$ & 41.73 & 40.06 & 39.06 & 34.21 & 31.18 & 29.65 & 28.75 & 27.06 & 25.08 & 31.67 & 40.02 & 43.03 \\
Phytoplankton & ind./1 & 1350 & 842 & 1013 & 1148 & 1193 & 1458 & 1746 & 2223 & 2196 & 1917 & 1782 & 1532 \\
Zooplankton & Ind./1 300 & 187 & 225 & 255 & 265 & 324 & 388 & 494 & 488 & 426 & 396 & 340 \\
Rotifera & ind./1 & 180 & 105 & 119 & 127 & 141 & 160 & 207 & 266 & 248 & 228 & 211 & 196 \\
Copepoda & ind./1 67 & 43 & 59 & 61 & 65 & 83 & 92 & 135 & 125 & 103 & 98 & 73 \\
Cladocera & ind./1 53 & 39 & 47 & 67 & 59 & 81 & 89 & 93 & 115 & 95 & 87 & 71 \\
\hline
\end{tabular}

$\mathrm{CO}_{2}$ showed positive correlation with $\mathrm{Ca}(\mathrm{r}=0.94561)$ while inversely related with phytoplankton $(\mathrm{r}=-0.54098)$, zooplankton $(\mathrm{r}=-0.54149)$, rotifera $(\mathrm{r}=-$ $0.40802)$, copepoda $(\mathrm{r}=-0.62372)$ and cladocera $(\mathrm{r}=-0.68006)$.

$\mathrm{Ca}$ showed negative correlation with phytoplankton $(\mathrm{r}=-0.59312)$, zooplankton $(\mathrm{r}=-0.59355)$, rotifera $(\mathrm{r}=-0.47622)$, copepoda $(\mathrm{r}=-0.66831)$ and cladocera $(\mathrm{r}=-0.69705)$. Phytoplankton showed positive correlation with zooplankton $(\mathrm{r}=0.999999)$, rotifera $(\mathrm{r}=0.983265)$, copepoda $(\mathrm{r}=0.979812)$ and cladocera $(\mathrm{r}=0.933722)$. Zooplankton showed positive correlation with rotifera $(\mathrm{r}=0.983187)$, copepoda $(\mathrm{r}=0.979925)$ and cladocera $(\mathrm{r}=0.933767)$. Rotifera showed positive correlation with copepoda $(r=0.9438)$ and cladocera $(r=$ $0.864744)$. Copepoda showed positive correlation with cladocera $(\mathrm{r}=0.91172)$.

Miah et al. (1981) found that zooplankton showed positive correlation with $\mathrm{CO}_{3}^{-}$and $\mathrm{HCO}_{3}$ alkalinity. Rahman \& Hussain (2008) found that zooplankton showed significant positive correlation with $\mathrm{pH}, \mathrm{DO}$ and $\mathrm{CO}_{2}$. Siddique et al. (2011) found that zooplankton showed positive correlation with $\mathrm{pH}, \mathrm{DO}, \mathrm{CO}_{2}$ and alkalinity where negative correlation found with water temperature and transparency.

The importance and influence of the physico-chemical factors on the phytoplankton and zooplankton are understood to assess the seasonal fluctuation of phytoplankton and zooplankton; all these factors; should be considered separately or collectively. No single factor is responsible for production or fluctuation. Hence for studying the growth, distribution and 
fluctuation of phytoplankton and zooplankton population all the physical, chemical and biological factors should be taken into consideration.

\section{LITERATURE CITED}

AHMED, K.K., HAQUE, M.K.I. and HAQUE, M.E. 1999. Studies on some physico-chemical factors of Kaptai lake. Bangladesh J. Fish. Res. 3(1): 33-39.

AHMED, K.K.U., HASAN, K.R., AHAMED, S.U., AHMED, T. and MUSTAFA, G. 2010. Ecology of the Shapla beel, Brahmanbaria. Bangladesh J. Zool. 38(1): 93-104.

ALI, M.L. 1985. Inland fisheries resources, present status and future potential in Bangladesh. Souvenir: National Seminar'85 on Fisheries Development in Bangladesh. BARC Dhaka. pp. 25-33.

AMEEN, M., BEGUM, Z.N.T. and ALI, S. 1986. A comparative limnological study of two fish ponds in Raipur. Dhaka University Studies, Part E 1(1): 25-34.

APHA, 1975. Standard Methods for the Examination of Water and Wastewater (14th ed.). American Public Health Association, Washington. 1125 pp.

AZHER, S.A., KHANOM, F. and DEWAN, S. 2006. Impact of fish sanctuaries on the production and diversity of plankton in beels of haor region in Bangladesh. Bangladesh J. Fish. Res. 10(2): 139-150.

BEGUM, A. 1958. A short note on plankton of freshwater ponds of Dacca. Agriculture Pakistan 9: 370-392.

BEGUM, A., MUSTAFA, G., ALI, S. and AHMED, K. 1989. Studies on limnology in a minipond and growth of Tilapia (= Oreochromis) nilotica. Bangladesh J. Zool. 17(1): 35-45.

BHOUYAIN, A.M. and ASMAT, G.S.M. 1992. Freshwater Zooplankton from Bangladesh (1 ${ }^{\text {st }}$ ed.). Ghazi Publishers, Banglabazar, Dhaka. 137 pp.

BHOUYAIN, A.M., DEY, J.P. and RAHMAN, M.H. 2005. Limnology of Bayezid Bostami pond in Chittagong. The Chittagong Univ. J. Sci. 29(2): 123-125.

BHOUYAIN, A.M. and SEN, H. 1983. Cladocera of Foy's lake. Chittagong Univ. Stud. Part. II: Sci. 7 (1): 29-39.

BHOUYAIN, A.M. and SEN, H. 1991. Primary productivity of Foy's lake, Chittagong, Bangladesh. Univ. J. Zool. Rajshahi Univ. 8: 77-84.

BHUIYAN, A.S. and ISLAM, M. 1988. Seasonal variation in the percentage composition of the food of Xenontodon cancila. Univ. J. Zool. Rajshahi Univ. 7: 33-36.

BHUIYAN, A.S. and NESSA, Q. 1998a. Seasonal variation in the occurrence of some zooplankton in a fish pond. Bangladesh J. Fish. Res. 2(2): 201-203.

BHUIYAN, A.S. and NESSA, Q. 1998b. A quantitative study of zooplankton in relation to the physicochemical conditions of a fresh water fish pond of Rajshahi. Univ. J. Zool. Rajshahi Univ. 17: 29-37.

BHUIYAN, A.S., ISLAM, S.N. and BHUIYAN, S. S. 2008. Seasonal occurrence of some copepods in relation to the physico-chemical conditions of a fish pond in Rajshahi, Bangladesh. Fishing Chimes India 28(4): 39-41.

CAMPOS, H., STEFFEN, W., AGUERO, G., PARRA, O. and ZUNIGA, L. 1992. Limnological studies of Lake Rupanco (Chile) morphometry, physics, chemistry, plankton and primary productivity. Arch. Hydrobiol. 1: 85-113. 
CHOWDHURY, S.H. and BHOUYAIN A.M. 1981. The Rotarian genera Brachionus Pallas and Platyias Harring from the river Karnaphuli. Bangladesh J. Zool. 9(11): 113-123.

CHOWDHURY, A.N., BEGUM, S. and SULTANA, N. 1989. Occurrence and seasonal variation of zooplankton in a fish pond in relation to some physico-chemical factors. Bangladesh J. Zool. 17(2): 101-106.

CHOWDHURY, A.N., BEGUM, S. and SUlTANA, N. 1992. Physico-chemical and biological parameters affecting the occurrence and seasonal variation of ostracods in a tropical fish pond. Bangladesh J. Zool. 20(2): 315-323.

CHOWDHURY, M.N.U. 1997. Studies on the ecology of the copepoda of Kaptai lake, Bangladesh. M.Sc. Thesis, Department of Zoology, University of Chittagong, Bangladesh. 152 pp.

CHOWDHURY, M.M. and RAKNUZZAMAN, M. 2005. Zooplankton communities in the polluted water of the river Buriganga, Dhaka, Bangladesh. Bangladesh J. Zool. 33(2): 177-182.

CHOWDHURY, A.H. and MAMUN, A.A. 2006. Physico-chemical conditions and plankton population of two fish ponds in Khulna. Univ. J. Zool. Rajshahi Univ. 25: 41-44.

CHOWDHURY, M.M.R., MONDOL, M.R.K. and DEWAN, S. 2008. Seasonal dynamics of plankton in relation to some environmental factors in a beel ecosystem. Univ. J. Zool. Rajshahi Univ. 27: 55-58.

DAS, N.G. 1974. Studies on Bangladesh copepoda. I. A new species of Heliodiaptomus (copepoda: calanoida) from Dhaka with a brief note on its ecology. Bangladesh J. Zool. 2(1): 47-51.

DAS, S.M. and SRIVASTAVA, V.K. 1956. Qualitative studies on fresh water plankton of a fish tanks in Lucknow, India. Proc. Nat. Acad. Sci. India 26(3): 85-91.

DAS, N.G. and BHUIYAN, A.L. 1974. Limnoplankton of some inland water of Dhaka city. Bangladesh J. Zool. 2(1): 27-42.

HOSSAIN, S.M.Z., CORRE, J.V. and TOLEDO, C.F. 1993. Effects of some physico-chemical parameters on the growth and survival of Penaeus monodon (Tabricius) in brackishwater ponds. Bangladesh J. Zool. 21(2): 27-36.

HOSSAIN, M.S., MAZID, M.A., EHSHAN, M.A., RAHMAN, S., ISLAM, A.K.M.S. and HOSSAIN, M.M.M. 1998. Limnological observations on Basukhali-Salimpur-Kola-Barnal (BSKB) beel. Part II: Plankton study. Bangladesh. J. Zool. 26(1): 79-84.

HOSSAIN, M.K., HOSSAIN, M., RAHMAN, M.H., AFZA, R. and KHANOM, D.A. 2008. Physicochemical condition of two nursery ponds at Iswarganj, Mymensingh. Univ. J. Zool. Rajshahi Univ. 27: 43-46.

HOSSAIN, M.S. and HAQUE, M.M. 2012. Physico-chemical variables and their effect on the growth performance of some major carps in some ponds of a matsaya gram (fish village) in Natore. Univ. J. Zool. Rajshahi Univ. 31: 55-58.

HUSSAIN, M.G., ISLAM, M.A. and CHOWDHURY, M.V. 1978. A study of the relationship between primary productivity and some limnological parameters in a local pond in Mymensingh. Bangladesh J. Fish 20(1): 113-119.

IQBAL, M.A. 1998. Studies on some limnological aspects of Parbattya lake, Bandarban Hill Tract, Chittagong. M.Sc. Thesis, Department of Zoology, University of Chittagong, Bangladesh. 101 pp.

ISLAM, A.K.M.N., HAROON, A.K.Y. and ZAMAN, K.M. 1974. Limnological studies of the river Buriganga, Bangladesh. Dacca Univ. Stud. B. 22(2): 99-111.

ISLAM, A.K.M.N. and HAROON, A.K.Y. 1975. Limnological studies of the river Burigangra. II. Biological aspect. Dacca Univ. Stud. B. 23(1): 25-44. 
ISLAM, A.K.M.N. and SAHA, J.K. 1975. Limnological studies of the Ramna lake at Dhaka (Dacca). Dacca Univ. Stud. B. 24(2): 39-46.

ISLAM, A.K.M.N. and MENDES, F. 1976. Limnological studies of a jheel in Sher-e-Bangla Nagar. Dacca Univ. Stud. B. 24(2): 63-71.

ISLAM, M.A., CHOWDHURY, M.Y. and KARIM, A.R. 1978. A comparative study of some physicochemical factors and the growth of major carps in pond. J. Aqua. 1(1): 61-78.

ISLAM, M.M., RASHID, M.M., ULLAH, S.M. and CHOWDHURY, N. 2002. Water quality evaluation in and around Dhaka city. Dhaka Univ. J. Biol. Sci. 11(2): 189-198.

KABIR, A.K.M.N., ALI, S. and KHONDKER, M. 1996. Study on the zooplankton from Gumti flood plain, Comilla. Dhaka Univ. J. Biol. Sci. 5(2): 129-135.

KABIR, A.K.M.N., ALI, S. and KHONDKER, M. 1997. Study on the zooplankton from Noakhali north flood plain. Dhaka Univ. J. Biol. Sci. 6(1): 31-37.

KABIR, A.K.M.N. and NASER, M.N. 2008. Qualitative and quantitative study of zooplankton in Chandbill baor of Meherpur district, Bangladesh. Bangladesh J. Zool. 36(1): 69-75.

KHAN, M.A.G. and CHOWDHURY, S.H. 1994. Physical and chemical limnology of lake Kaptai, Bangladesh. Tropical Ecology 35(1): 35-51.

KHONDKAR, M., ISLAM, A.K.M.N., TAHMIDA, Z.U. and HAQUE, S. 1990. Limnological studies of four polluted ponds in and around Dhaka city with reference to indicator species. Bangladesh $J$. Bot. 19(1): 51-64.

KHONDKAR, M. and RAHIM, S. 1991. Investigation on the water quality of Dhanmondi lake. I. Physico-chemical features. Bangladesh J. Bot. 20(2): 183-192.

KHONDKAR, M. and PARVEEN, L. 1992. Study of the physical and chemical limnology of a shallow hypertrophic artificial lake. Bangladesh J. Sci. Res. 10(1): 9-16.

LATIF, M.A., ALI, M.M. and ISLAM, M.A. 1986. A comparative physico-chemical study of a well managed fish pond and a derelict pond. Bangladesh J. Aqua. 7(1): 71-78.

LATIFA, G.A., AHMED, M.S. and HOSSAIN, M.K. 2008. Induced breeding of Channa striatus (BLOCH, 1793). Bangladesh J. Zool. 36(2): 149-154.

MAJUMDAR, A. 1980. Studies on some limnobiological aspects of Kaptai lake. M.Sc. Thesis, Department of Zoology, University of Chittagong. pp. 44-56.

MAMUN, A.A., SANDER, M.R.I. and RAHMAN, M.M. 2010. Growth performance of genetically male (GMT) and hormone induced sex reserved male tilapia (Oreochromis nilotica L.) in earthen pond Aquaculture System. Bangladesh J. Zool. 38(2): 163-169.

MATHEW, P.M. 1975. Limnology and productivity of Govindgarh lake. Rewa, Madhya Pradesh. J. Inland Fish. Soc. India 7: 16-24.

MIAH, M.I., BHUIYAN, N.I and DEWAN, S. 1981. A comparative study on the rate of growth of major carps in relation to physico-chemical and biological factors. Proceedings of Zoological Society of Bangladesh. pp. 215-224.

MOZUMDER, P.K., NASER, M.N., ALI, M.S., ALAM, M., HUQ, A., SACK, R.B. and COLWELL, R.R. 2010. Qualitative and quantitative analysis of some coastal water bodies of Bakerganj, Bangladesh. Bangladesh J. Zool. 38(1): 127-132.

MOZUMDER, P.K., NASER, M.N., ALAM, M., SACK, R.B., COLWELL, R. R. and HUQ, A. 2011. A taxonomical study of the rotifera fauna of Mathbaria in Southern part of Bangladesh. Bangladesh J. Zool. 39(1): 1-10. 
NAHAR, S., NASER, M.N., ALAM, M., MOZUMDER, P.K. and ALI, M.S. 2008. Rotifer fauna of three pristine coastal ponds from South-western Bangladesh. Bangladesh J. Zool. 36 (2): 305-307.

NAZ, S. and NAJIA, S. 2008. Study on the zooplankton of Sona Dighi in Rajshahi, Bangladesh. Univ. J. Zool. Rajshahi Univ. 27: 7-11.

NESSA, M. 1996. Studies on the ecology of the zooplankton of a pond of Agrabad area, Chittagong, Bangladesh. M.Sc. Thesis, Department of Zoology, University of Chittagong. 129 pp.

PRASAD, B.B. and SINGH, R.B. 2003. Composition, abundance and distribution of phytoplankton and zoobenthos in a tropical water body. Nat. Envin. Pollut. Technol. 2: 255-258.

RAHAMAN, M.M. 2004. Qualitative and quantitative study of plankton in relation to some water quality parameters in two beels. M.Sc. Thesis, Department of Aquaculture, Bangladesh Agricultural University, Mymensingh. 119 pp.

RAHMAN, M.M. BEGUM, A., AHMED, M.S. and ALI, M.S. 2007. Abundance and seasonal succession of phytoplankton in Hamil beel, Tangail. Bangladesh J. Zool. 35(1): 27-32.

RAHMAN, S. and HUSSAIN, M.A. 2008. A study on the abundance of zooplankton of a culture and a non-culture pond of the Rajshahi University Campus. Univ. J. Zool. Rajshahi Univ. 27: 35-41.

RAMAKRISHNAIAH, M. and SARKAR, S.K. 1982. Plankton productivity in relation to certain hydrobiological factors in Konar reservoir (Bihar). J. Inland Fish. Soc. India 14(1): 58-68.

RANA, S.V.S. 2003. Essentials of Ecology and Environmental Science. Prentic-Hall of India Pvt. Ltd., New Delhi. pp. 75-77.

SAHA, G.N., SEHGAL, K.L., MITRA, E. and NANDY, A.C. 1971. Studies on the seasonal and diurnal variations in physico-chemical and biological conditions of a perennial freshwater pond. $J$. Inland Fish. Soc. India III: 79-102.

SEN, H. 1982. Some limnological aspects (physio-chemical factors, plankton and primary productivity) of Foy's lake. M.Sc. Thesis, Department of Zoology, University of Chittagong. $80 \mathrm{pp}$.

SHIL, A.K. 1980. Comparative study on the limnology of two ponds, Kamal dighi and Lal dighi of Chittagong city. M.Sc. Thesis, Department of Zoology, University of Chittagong. pp. 56-70.

SIDDIQUE, M.A.B., HUSSAIN, M.A., HOSSAIN, M.A. and ALAM, M.M. 2011. Seasonal abundance of zooplankton and growth performance of prawn and fish in ponds of Rajshahi. Univ. J. Zool. Rajshahi Univ. 29: 13-15.

SWARUP, K. and SINGH, S.R. 1979. Limnological studies of Suraha lake (Ballia). I. Variations in the water quality. J. Inland Fish. Soc. India 11(1): 22-32.

VYES, L.N. and KUMAR H.D. 1968. Studies on the phytoplankton and other algae of Indrasagar tank Udaipur, India. Hydrobiol. 27: 529-547.

WELCH, P.S. 1952. Limnology. McGraw Hill Book Company, New York. pp. 33-92. 